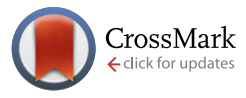

Cite this: Med. Chem. Commun., 2016, 7, 550

Received 6th November 2015 Accepted 22nd February 2016

DOI: $10.1039 / \mathrm{c} 5 \mathrm{md} 00515 \mathrm{a}$

www.rsc.org/medchemcomm

\section{Squaramides with cytotoxic activity against human gastric carcinoma cells HGC-27: synthesis and mechanism of action + t:}

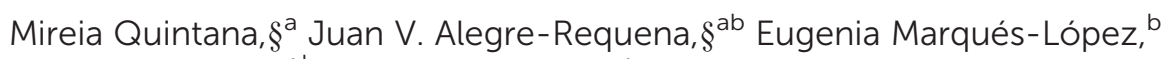 \\ Raquel P. Herrera*b and Gemma Triola*a
}

\begin{abstract}
A series of squaramates and squaramides have been synthesized and their cytotoxic activity has been investigated in different cancer cell lines. Among the studied compounds, squaramide 34 showed a potent and selective cytotoxicity against the human gastric cancer cell line HGC-27. Studies directed to elucidate the mechanism of induced cell death were performed. Cell cycle distribution analysis and cell death studies showed that compound 34 induces cell cycle arrest at the $G_{1}$ phase and caspase-dependent apoptosis. In conclusion, squaramide 34 can be considered a potential anticancer agent for gastric carcinoma.
\end{abstract}

\section{Introduction}

The field of squaramides has experienced an extraordinary growth since the work reported by Rawal and co-workers in $2008,{ }^{1}$ where these molecules were used as organocatalysts. Their promising properties also make them appealing for diverse areas of research beyond organocatalysis..$^{2-4}$

Their unique structural features are believed to have an effect on the biological activity of these substrates; squaramide structures present a planar aromatic framework ${ }^{5}$ bearing two adjacent carbonyl acceptor groups and two $\mathrm{NH}$ donor sites that are able to establish multiple hydrogen bond interactions. ${ }^{6}$ In this sense, due to their important ability to selectively bind through cooperative hydrogen bonds, squaramides have received special attention in medicinal chemistry since they may be able to interact with biological targets via specific molecular recognition. ${ }^{7}$

This has promoted recent interest of medicinal chemists in considering squaramide motifs as promising candidates for drug design and interesting tools as bioisosteres of ureas, guanidines or phosphates, among others. ${ }^{8-16}$ Moreover, squaramides exhibit an interesting dual behaviour, as they are able to act as good hydrogen bond acceptors and hydrogen bond donors, which make them suitable for both cation

\footnotetext{
${ }^{a}$ Biomedicinal Chemistry Department, Institute of Advanced Chemistry of Catalonia (IQAC), CSIC, E-08034, Barcelona, Spain.

E-mail: gemma.triola@iqac.csic.es

${ }^{b}$ Laboratorio de Organocatálisis Asimétrica, Departamento de Química Orgánica, Instituto de Sintesis Quimica y Catálisis Homogénea (ISQCH), CSIC-Universidad de Zaragoza, E-50009 Zaragoza, Spain. E-mail: raquelph@unizar.es

$\dagger$ The authors declare no competing interests.

\$ Electronic supplementary information (ESI) available. See DOI: 10.1039/ c5md00515a

$\S$ These authors equally contributed to this manuscript.
}

and anion recognition. This could be crucial for the success of cell internalization of these compounds, one of the most important issues in drug design.

In spite of the increasing number of bioactive squaramidebased compounds found in the literature, their application as anticancer agents has not yet been intensively explored and no exhaustive studies in different cancer cells have been previously reported. ${ }^{17,18}$ In addition, some squaramides have been shown to selectively bind protein kinases ${ }^{18}$ or the CXCR2 receptor, ${ }^{19}$ thus indicating that this class of compounds may exert their function by selectively binding to cellular targets. Hence, this interesting behaviour suggests that squaramides may serve as a good starting point to identify molecules that can specifically target cancer cells. This, together with the interest in searching for new anticancer agents, prompted us to evaluate the antitumor activity of a variety of squaramides synthesized following a protocol recently published by us. ${ }^{20-22}$

Based on these precedents, we envisioned that the ability of squaramides to generate hydrogen bonds and electrostatic interactions could be an interesting option to design specific recognition systems with potential antitumor effects. Herein, we present a series of squaramides and squaramates and the study of their activity against different cancer cells that confirms the antitumor properties of this family of promising drug candidates.

\section{Results and discussion}

Firstly, following our optimized reaction conditions, ${ }^{20,22}$ a series of differently substituted squaramates 1-14 and squaramides 15-39 were synthesized (Charts 1 and 2). Substituents with different stereoelectronic properties and 

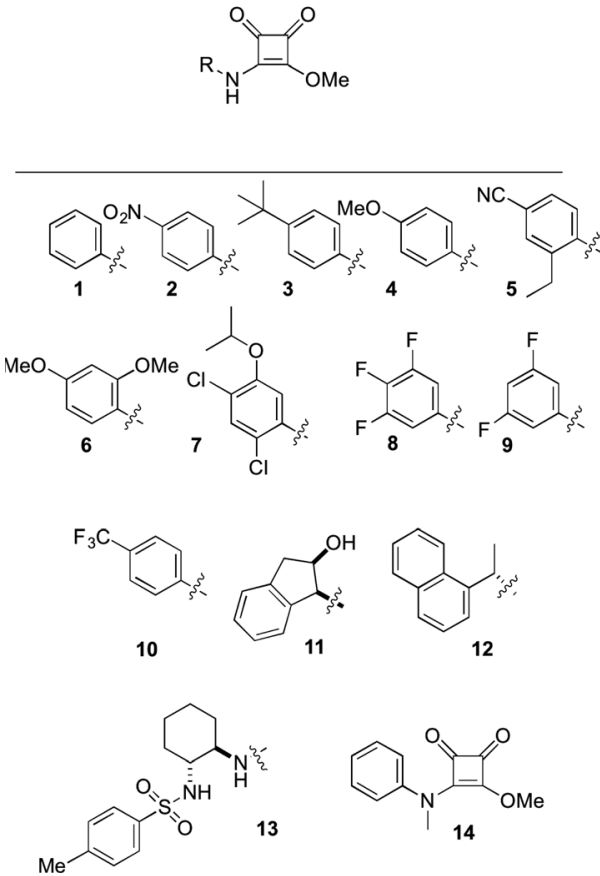
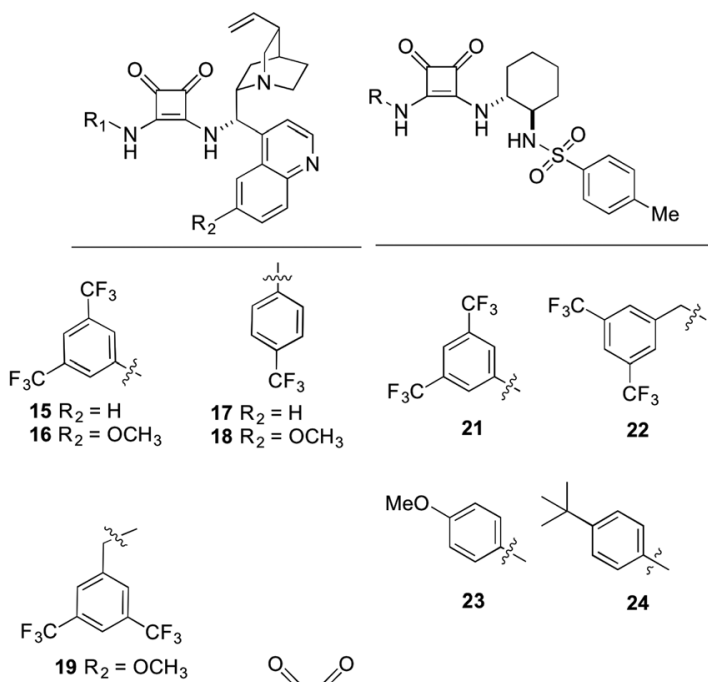

$19 \mathrm{R}_{2}=\mathrm{OCH}_{3}$

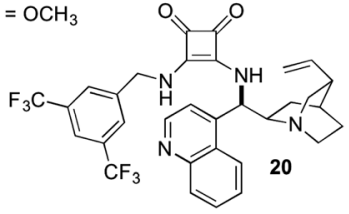

Chart 1 Squaramates and squaramides evaluated.<smiles>[R]NC1NC(NC2CCCCC2N2CCCCC2)C(=O)C1=O</smiles><smiles></smiles>

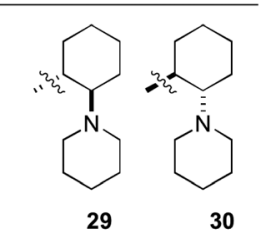<smiles>FC(F)(F)c1cccc(C(F)(F)F)c1</smiles>

27<smiles>Oc1ccc2ccccc2c1-c1c(C(F)(F)F)ccc2ccccc12</smiles>

25<smiles>Fc1cc([AlH2])cc(F)c1F</smiles><smiles>[R]c1c(Nc2cc(F)cc(F)c2)c(=O)c1=O</smiles><smiles>CC(NC(C)c1cccc2ccccc12)c1cccc2ccccc12</smiles><smiles>CNC(c1ccccc1)c1ccccc1</smiles><smiles>O=c1c(Nc2ccc3ccccc3c2-c2c(O)ccc3ccccc23)c(NC2CCCCC2N2CCCC2)c(=O)c1=O</smiles><smiles></smiles>

Chart 2 Squaramides evaluated.

lipophilicities were incorporated with the aim of investigating if their biological activity may correlate with the presence of different $\mathrm{NH}$ amide-type donor sites.

\subsection{Cell-type specific cytotoxic effect of squaramides}

The effect of squaramides on cell viability was initially evaluated on different tumor cell lines (HeLa, cervical carcinoma, and HGC-27, gastric carcinoma) using an MTT assay after $24 \mathrm{~h}$ of treatment at $100 \mu \mathrm{M}$ (Fig. 1).

As shown in Fig. 1, treatment with some of the compounds resulted in significant loss of cell viability. Some structure-activity relationships can be disclosed from this initial screening. Hence, squaramates 1-14 (Chart 1) showed no remarkable activity in any of the cases, thus indicating that the second $\mathrm{NH}$ amide bond is required for activity. 


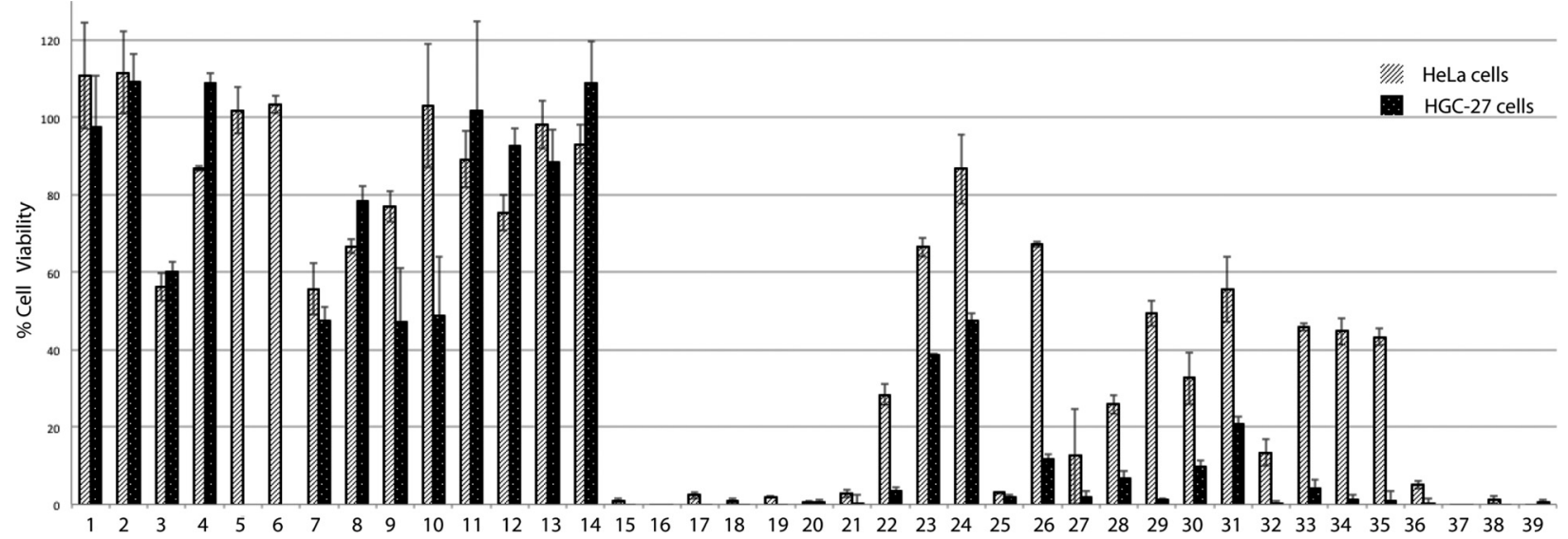

Fig. 1 Percentage of cell viability after $24 \mathrm{~h}$ of treatment with a concentration of $100 \mu \mathrm{M}$ as measured by an MTT assay. The cells were grown on a 96-well plate and treated with the squaramides or DMSO (vehicle group). After $24 \mathrm{~h}$ of treatment, cell viability was evaluated using an MTT assay, as described in the Experimental section. Cell viability is represented in relation to the vehicle group. Data are the average \pm SD of three experiments.

Substantial inhibition can be seen for compounds 15-20 all of them sharing a cinchona-based substituent. Interestingly, the presence of a 3,5-bis(trifluoromethyl)phenyl moiety confers almost in all the cases inhibition of cell viability $(15,16$, 21, 27, 34-38), irrespective of the other substituent present at the second amide. Similarly, 3,5-bis(trifluoromethyl)benzyl substituted squaramides 22 and 26 also show good activities in HGC-27 cells, whereas they are less active in HeLa cells.

After this initial screening, the most potent compounds were selected and were further evaluated at $20 \mu \mathrm{M}$ (Fig. 2). Interesting information was revealed from this second screening. In general, HGC-27 cells seem to be more sensitive than HeLa cells to the effect of the tested squaramides, except for compound 27 which shows a more potent cell viability inhibitory activity in HeLa cells than in HGC-27. This celltype specificity may discard a general non-specific cytotoxic effect exerted by the squaramides. Again, the cinchona-based compounds 15-20 showed good inhibitory activities, independently of the substituents present at the other point of diversity. Squaramides containing bulky and chiral substituents at both sites $(25,39)$ are more potent than the corresponding $p$-trifluoromethylphenyl analogues $(29,30)$. The 3,5-bis(trifluoromethyl)phenyl substituted squaramides 34-38 displayed different potencies depending on their substitution pattern, with the highly lipophilic 33 and 34 being the most potent compounds. As a result of this second screening, squaramides 21, 22, 28-30, 32 and 35-37 were discarded due to the low potency displayed at $20 \mu \mathrm{M}$ and, consequently, $\mathrm{IC}_{50}$ values were measured for the remaining compounds (Table 1).

The increased sensitivity of HGC-27 cells compared to HeLa cells was again proven, showing in all the cases $\mathrm{IC}_{50}$ values in the low micromolar range for all the tested squaramides. Interestingly, squaramide 34, bearing a 1,1,2triphenylethanol and a 3,5-trifluoromethylphenyl substituent,

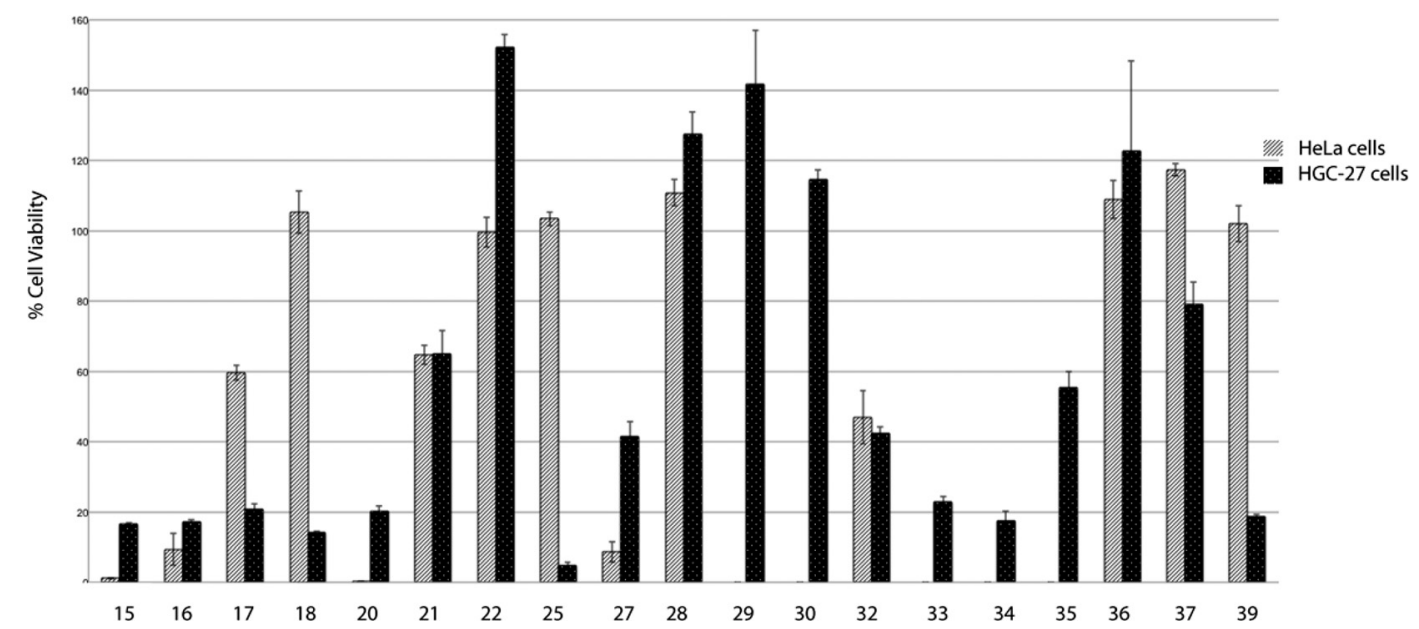

Fig. 2 Percentage of cell viability after $24 \mathrm{~h}$ of treatment with a concentration of $20 \mu \mathrm{M}$ as measured by an MTT assay. The cells were grown on a 96 -well plate and treated with the squaramides or DMSO (vehicle group). After $24 \mathrm{~h}$ of treatment, cell viability was evaluated using an MTT assay, as described in the Experimental section. Cell viability is represented in relation to DMSO. Data are the average \pm SD of three experiments. Note: compounds 29, 30 and 33-35 were not investigated in HeLa cells at $20 \mu \mathrm{M}$. 
Table 1 Effect of squaramides on cell viability against HeLa and HGC-27 cell lines as measured by an MTT assay. Cisplatin and doxorubicin were added as a positive control. $I C_{50}$ values are indicated as the average \pm SD of three experiments

\begin{tabular}{llc}
\hline & \multicolumn{2}{l}{ Mean $\mathrm{IC}_{50}(95 \% \mathrm{CI})$ in $\mu \mathrm{M}$} \\
\cline { 2 - 3 } Compound & HeLa cells & HGC-27 cells \\
\hline $\mathbf{1 5}$ & $11.26(10.33-12.2)$ & $8.12(7.14-9.24)$ \\
16 & $15.17(13.2-17.4)$ & $8.21(7.68-8.78)$ \\
17 & $10.79(9.49-12.26)$ & $4.53(3.83-5.36)$ \\
18 & $>20$ & $12.76(11.84-13.7)$ \\
20 & $12.08(11.37-3.93)$ & $3.01(2.26-5.02)$ \\
25 & $>20$ & $11.11(10.51-11.74)$ \\
33 & $>20$ & $3.39(2.85-4.04)$ \\
34 & $34.63(27.97-42.87)$ & $1.81(1.47-2.23)$ \\
39 & $>20$ & $10.79(10.30-11.20)$ \\
Cisplatin & - & $20.44(19.84-22.18)$ \\
Doxorubicin & - & $37.40(30.63-45.67)$
\end{tabular}

was found to be one of most potent and selective compounds tested, showing an $\mathrm{IC}_{50}$ value of $34.63 \mu \mathrm{M}$ in HeLa cells and $1.81 \mu \mathrm{M}$ in HGC-27 cells. Analogously, squaramide 33, where the 3,5-bis(trifluoromethyl)phenyl had been replaced by 3,5-difluorophenyl, displayed a similar activity pattern. Moreover, this low micromolar $\mathrm{IC}_{50}$ decreased further to nanomolar values (660 nM, Table 2) when HGC-27 cells were exposed to compound 34 for $48 \mathrm{~h}$.

With these promising results in hand regarding the activity and selectivity of squaramide 34 , we decided next to explore the activity profile of $\mathbf{3 4}$ on different cell lines. Hence, cell viability studies were extended to the glioblastoma cells lines, T98 and U87 (the most aggressive type of primary brain tumor) and the non-cancer cells HEK293, MDCK (MadinDarby Canine Kidney Epithelial cells) and the Vero cell line (African green monkey kidney cell line). The results are displayed in Table 2 and confirm certain cell-dependent toxicity $\left(\mathrm{IC}_{50}\right.$ values of $60.25 \mu \mathrm{M}$ and $7.15 \mu \mathrm{M}$ for the glioblastoma cell lines U87 and T98, respectively, 9.03 $\mu \mathrm{M}$ for the HEK293 cells, 70.20 $\mu \mathrm{M}$ for the MDCK cells and 33.40 $\mu \mathrm{M}$ for the Vero cells).

Gastric cancer accounts for $8 \%$ of the total cases of cancers and $10 \%$ of total deaths. The survival for patients with this type of cancer has improved only modestly over the last 50 years. Consequently, there is still a clear need for the development of more efficient treatments. Moreover, gastric cancer presents high molecular heterogeneity, which prevents the uniform application of specific targeted agents, ${ }^{23}$ and therefore the identification of novel targets or novel com- pounds active on gastric cancer cells is of great interest. ${ }^{23,24}$ With this aim, and due to the high potency displayed by 34 in the gastric cancer cells HGC-27 together with its interesting selectivity profile observed in the other cell lines, we aimed to further examine the molecular mechanisms underlying 34-mediated cell death in HGC-27 cells.

\subsection{Apoptotic cell death study}

The MTT assay reflects viable cells but cannot be employed as a marker of cell proliferation. A decrease in the number of viable cells can be attributed to cell cycle arrest and/or cell death. To determine whether 34-induced decrease in cell viability in HGC-27 cells was accompanied by alterations in cell cycle distribution, the percentage of cells in the different stages of the cell cycle was analysed by flow cytometry. As shown in Fig. 3, treatment with 34 for $24 \mathrm{~h}$ induced a significant accumulation of $\mathrm{G}_{0} / \mathrm{G}_{1}$ cells associated with a decrease in the $S-G_{2} / M$ cell population, suggesting that cell cycle arrest at the $G_{0} / G_{1}$ phase contributes to the observed effect, whereas treatment of cells with doxorubicin, included as a positive control, resulted in $\mathrm{G}_{2} / \mathrm{M}$ arrest.

Cell death can be controlled by several mechanisms or pathways. ${ }^{25}$ Therefore, we decided to quantify the cell death caused by 34 as well as determine the specific cell death modality, which is mainly apoptosis, necrosis or autophagy that may be prevalent in these cells. With this aim, we evaluated the apoptotic effect of 34 on HGC-27 cells using an Annexin V-FITC/PI staining assay and analysed the stained cells by flow cytometry. ${ }^{26}$ Briefly, loss of plasma membrane integrity is indicative of cell death and this can be assessed using cell-impermeable dyes that are able to enter the cell once the integrity of the plasma membrane is lost, such as propidium iodide (PI). Moreover, apoptotic cells expose phosphatidylserine (PS) before membrane rupture, whereas in necrotic cells PS exposure and membrane disruption occur simultaneously, thus discriminating early and late apoptotic cells as well as necrotic cells. To study the effect of 34 on HGC-27 cells, cells were treated with the vehicle alone as control or with 34 at three different concentrations $(1,2.5$ and $8 \mu \mathrm{M})$. After 24 hours, the samples were double stained with Annexin V-FITC and PI and the percentage of cells was analysed. As shown in Fig. 4, compound 34 induced cell apoptosis in a concentration-dependent manner. In the case of $1 \mu \mathrm{M}, 2.5 \mu \mathrm{M}$ and $8 \mu \mathrm{M}$ treated HGC-27 cells, the total percentage of early and late apoptotic cells were $2.4 \%, 24.7 \%$,

Table 2 Effect of squaramide 34 on cell viability against various human cancer cell lines as measured by an MTT assay. IC 50 values are indicated as the mean \pm SD of three experiments

\begin{tabular}{llllllll}
\hline \multirow{2}{*}{ Compound } & \multicolumn{2}{l}{ Mean $\mathrm{IC}_{50}(95 \% \mathrm{CI})$ in $\mu \mathrm{M}$} & & & \\
\cline { 2 - 7 } & HeLa & HGC-27 & T98 & U87 & HEK293 & MDCK & Vero \\
\hline 34 & 34.63 & $1.81(1.47-2.23)$ & 7.15 & 60.25 & 9.03 & 70.20 \\
& $(27.97-42.87)$ & $0.66^{a}$ & $(6.12-8.34)$ & $(41.52-87.42)$ & $(7.07-11.54)$ & $(50.58-97.43)$ & $(27.96-39.90)$
\end{tabular}

${ }^{a} \mathrm{IC}_{50}$ measured after $48 \mathrm{~h}$ of treatment. 
A
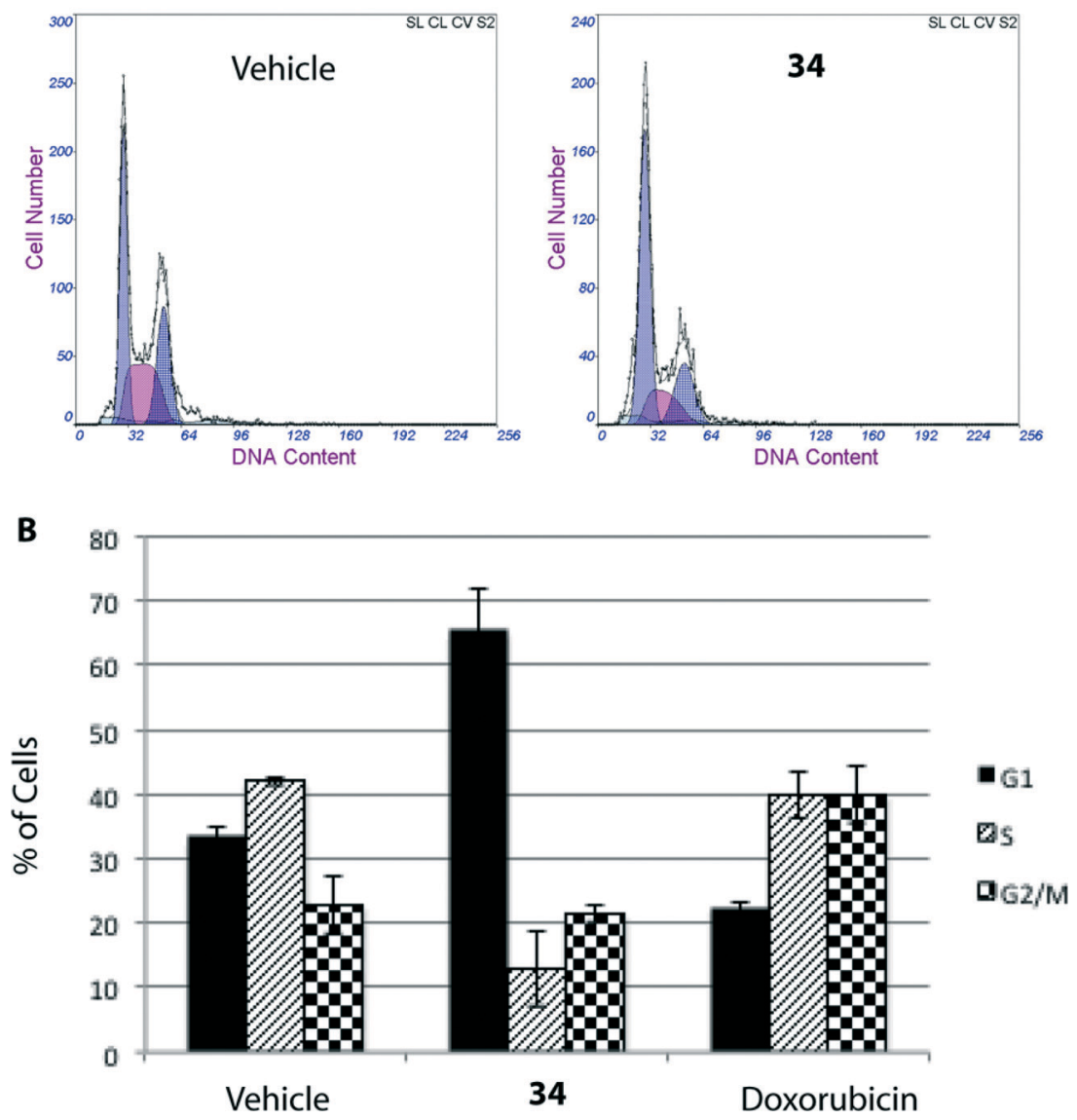

Fig. 3 Cell cycle distribution of HGC-27 cells with or without treatment of compound 34 at $5 \mu \mathrm{M}$ in DMSO for $24 \mathrm{~h}$. Doxorubicin (500 nM) was included as a positive control. The cells were collected and processed for cell cycle analysis. A) Representative cell cycle histograms obtained from HGC-27 cells after $24 \mathrm{~h}$ of exposure to vehicle or 34 . B) Quantification of the relative number of cells in each stage of the cell cycle (Multicycle AV software). Data are the average \pm SD of three experiments.

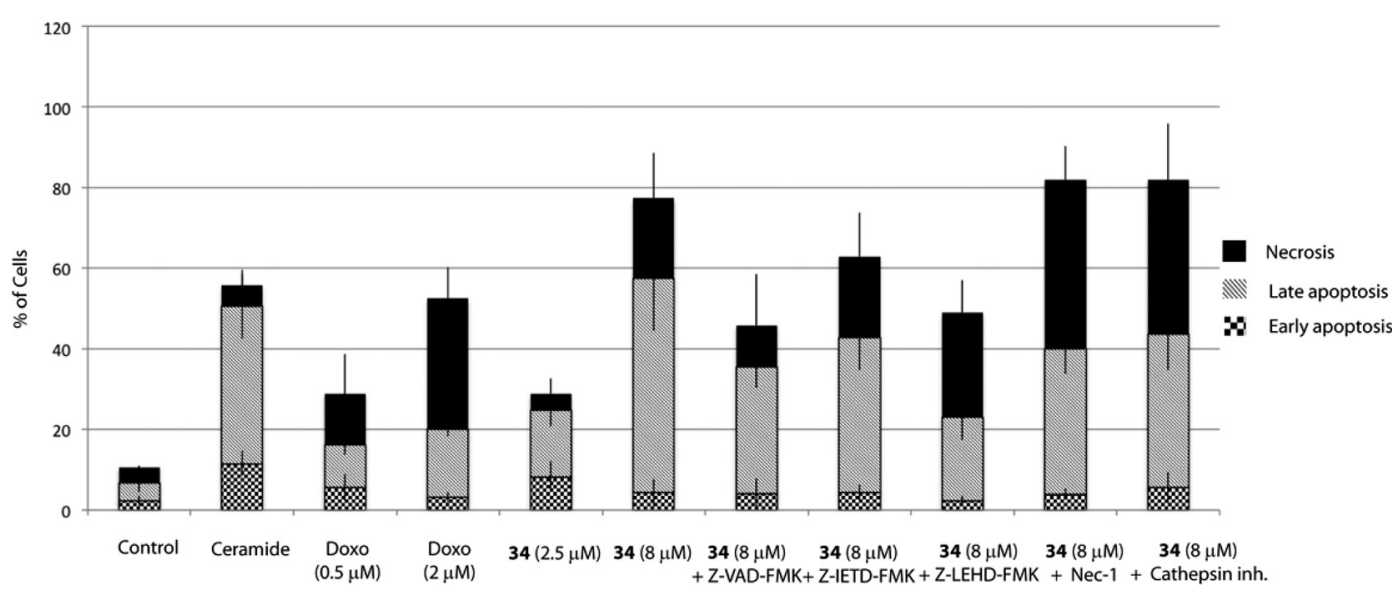

Fig. 4 Apoptotic effect of squaramide 34 on HGC-27 cells. Cells were treated with DMSO (vehicle group) or 34 alone or together with Z-VADFMK $(20 \mu \mathrm{M})$, Z-IETD-FMK $(20 \mu \mathrm{M})$, Z-LEHD-FMK $(20 \mu \mathrm{M})$, Nec-1 $(10 \mu \mathrm{M})$ or cathepsin inhibitor III $(10 \mu \mathrm{M})$. Cells were pre-treated for $1 \mathrm{~h}$ with Z-VAD-FMK, Z-IETD-FMK, Z-LEHD-FMK and cathepsin inhibitor III and $3 \mathrm{~h}$ with Nec-1 before adding 34. C8-ceramide (20 $\mu \mathrm{M})$ was added as a positive control. After $24 \mathrm{~h}$ of treatment, the cells were double-stained with Annexin V and PI and analysed. The percentage of apoptotic and necrotic cells upon incubation with 34 were quantified by flow cytometry as described in the Experimental section (live cells (bottom left quadrant), early apoptotic cells (bottom right quadrant), late apoptotic cells (upper right quadrant) and necrotic cells (upper left quadrant)). The graph shows the quantitative analysis of necrosis and early and late apoptosis in treated cells. The data were obtained from three independent experiments. 
and $60.1 \%$, respectively. In contrast, only $6.7 \%$ of the early and late apoptotic cells were detected in the control, which revealed that compound $\mathbf{3 4}$ efficiently induces apoptosis in HGC-27 cells (Fig. 4). Doxorubicin and cisplatin have been used for the treatment of gastric cancer, usually in combination with other anticancer agents. Therefore, the effect of doxorubicin in HGC-27 cells was also investigated, resulting in dose-dependent induction of apoptosis. HGC-27 cells treated with a concentration of $2 \mu \mathrm{M}$ of doxorubicin ${ }^{27}$ presented $3.2 \%$ of early apoptotic cells, $16.7 \%$ of late apoptotic cells and $32.4 \%$ of necrotic cells, thus showing a slightly less potent effect than squaramide 34 .

To explain the high doses required to detect cell death compared to the $\mathrm{IC}_{50}$ values obtained in the MTT assays, we measured the effect of these compounds on cell viability by an alternative assay based on the quantification of cellular ATP levels. Indeed, although $\mathrm{IC}_{50}$ values resulting from these studies were in a similar range, the dose-dependent curve obtained in the ATP-based analysis was in agreement with concentrations required in cells to cause an apoptotic effect (Fig. S1\$). Alternatively, a sulforhodamine B (SRB) assay was employed to investigate the cytotoxicity of 34. SRB is a dye that binds proteins under mild acidic conditions, and the amount of detected dye can be correlated with the cell mass. ${ }^{28}$ Hence, the SRB assay is independent of the mitochondrial function. In this case, an $\mathrm{IC}_{50}$ of $9.74 \mu \mathrm{M}$ was obtained for squaramide 34 in HGC-27 cells (vs. $149 \mu \mathrm{M}$ and $73.85 \mu \mathrm{M}$ in MDCK and Vero cells, respectively). In contrast to the MTT assay that requires cellular metabolic activity and therefore only stains viable cells, SRB stains viable and dead cells, thus giving generally slightly higher $\mathrm{IC}_{50}$ values. ${ }^{28}$

\subsection{Squaramide 34 induces caspase-dependent cell death}

Apoptosis can be triggered through caspase-dependent or independent mechanisms. To explore whether 34 induces cell death through a caspase-dependent mechanism, Z-VAD-FMK, a pan-caspase inhibitor was employed. Hence, pre-treatment of cells with Z-VAD-FMK $(20 \mu \mathrm{M})$ for $1 \mathrm{~h}$ partially prevented 34-induced cell death, thus suggesting that a caspasedependent mechanism may be involved (Fig. 4).

Apoptosis may be initiated by the extrinsic or the intrinsic signaling pathway. The extrinsic signaling pathway involves death receptors located at the membrane, such as FasL/FasR and TNF- $\alpha$ TNFR1, the transmission of the signal from the cell surface to intracellular signaling pathways and the implication of caspase-8. The intrinsic pathway is the mitochondrial pathway and may be caused by different stimuli including free radicals, toxins, or hypoxia, and involves the activation of caspase-9. The extrinsic pathway and the intrinsic pathway converge on the final execution phase, mediated by the effector caspase- $3 .^{29}$ Hence, we next investigated the implication of both pathways by pre-treatment of the cells with a caspase-8 (Z-IETD-FMK) or a caspase-9 (Z-LEHD-FMK) inhibitor. Interestingly, the percentage of apoptotic cells decreased markedly upon treatment with the caspase- 9 inhibi- tor Z-LEHD-FMK, compared to the results obtained with the other caspase inhibitors, thus suggesting the implication of the mitochondrial pathway (Fig. 4). A smaller decrease in apoptosis rate was also observed when cells were treated with the caspase inhibitor Z-IETD-FMK, which could be due to the described cross reactivity for these inhibitors. ${ }^{30}$

\subsection{Alternative cell death mechanism}

Cathepsin-dependent cell death. Cell death can also be mediated by lysosomal cathepsin proteases in the so-called lysosomal cell death (LCD), consisting of lysosomal membrane permeabilization (LMP) and subsequent release of lysosomal proteases to the cytosol. ${ }^{31}$ Extensive LMP leads to uncontrolled necrosis, whereas limited LMP can activate caspase-dependent or independent pathways, ${ }^{32}$ resulting in a cell death that can be prevented upon cathepsin inhibition. Hence, to elucidate whether part of the cell death observed in 34-treated cells was due to a cathepsin-mediated process, cells were incubated with $\mathbf{3 4}$, with or without a cathepsin inhibitor cocktail (cathepsin inhibitor III, EMD Millipore) which primarily targets cathepsin $\mathrm{B}$, and the extent of cell death was then measured by an Annexin V-FITC/PI staining assay. As shown in Fig. 4, the presence of the cathepsin inhibitor did not have any effect on the percentage of live cells but on the contrary it did dramatically induce necrosis on HGC-27 cells. Treatment of HGC-27 cells with cathepsin inhibitor III alone did not have remarkable apoptotic effects (not shown). The obtained results discard the involvement of LCD in the molecular mechanism responsible for 34 effects.

Necrosis. Initial cell death analysis by flow cytometry studies revealed that $\mathbf{3 4}$ also causes a significant increase in the number of necrotic cells (Fig. 4). Necrosis may be primary or secondary. Secondary necrotic cells follow apoptosis, whereas primary necrosis, also termed necroptosis, is a nonapoptotic programmed cell death that is mediated by kinases of the receptor interacting protein (RIP) family. ${ }^{33}$ Hence, we then investigated if necroptosis could contribute to the caspase-independent cell death. With this aim, HGC-27 cells were pre-treated with Necrostatin-1 (Nec-1), an RIP1 inhibitor that blocks this pathway. Interestingly, the necrosis induced by 34 turned out to be not Nec-1 sensitive, thus discarding the involvement of necroptosis as a cell death method, and suggesting that the necrotic cells observed in the flow cytometry analysis are probably post-apoptotic cells.

Autophagy. Apart from apoptosis or necrosis, another mechanism of programmed cell death is associated with excessive levels of autophagy in a process known as autophagic cell death (ACD). ${ }^{34}$ Considering that an autophagic pathway could play a role in the 34-mediated effect, we determine whether this compound induces autophagy in HGC-27 cells and how this process may impact the cellular fate. Therefore, we evaluated the effects of squaramide 34 on autophagy by assessing a key marker of this process, LC3-II. During autophagosome formation, microtubule-associated protein 1 light chain 3 (LC3-I) gets lipidated at the C-terminus with a 
phosphatidylethanolamine unit (LC3-II) and subsequently associated with the autophagosome membrane. Since the amount of LC3-II correlates well with the number of autophagosomes, it has been widely employed to monitor autophagy. Hence, HGC-27 cells were treated with 34 for 24 $\mathrm{h}$, and the cell lysates were subjected to Western blotting to determine the changes in expression of LC3-II. As shown in Fig. 5, Western blot analysis revealed a minor increase in this specific autophagic marker after squaramide 34 treatment. Because autophagy is a dynamic process, LC3 accumulation can occur as a result of autophagy induction or due to impairment of the lysosomal function. Moreover, certain cells present a high basal autophagic flux, and as a consequence, autophagy induction is not always correlated with a clear LC3-II accumulation. ${ }^{35}$ To discard these possibilities, LC3-II levels were also measured upon inhibition of the lysosomal function. Indeed, these studies revealed a pronounced accu- mulation of LC3-II in 34-treated cells, indicating a correct autophagic flux, an unmasked LC3-II accumulation probably due to its rapid turnover and confirming an important autophagy induction.

Although it has been proven that autophagy can contribute to cell death, ${ }^{36}$ there is still a controversy whether it is a cell death caused by autophagy, or a cell death accompanied by induction of autophagy that may exert a survival or cytoprotective effect. $^{37,38}$ To determine how this autophagy induction impacts the cell fate, we aimed to test if autophagy plays a causative role in preventing 34-induced cell death by employing autophagy inhibitors. Herein, we used two autophagy inhibitors, chloroquine (CQ), a lysosomotropic agent that impairs the lysosomal function, and 3-methyladenine (3-MA), a pan inhibitor of the lipid kinase phosphatidylinositol 3-kinase (PI3K), involved in the first steps of autophagosome formation, and the percentage of apoptotic/

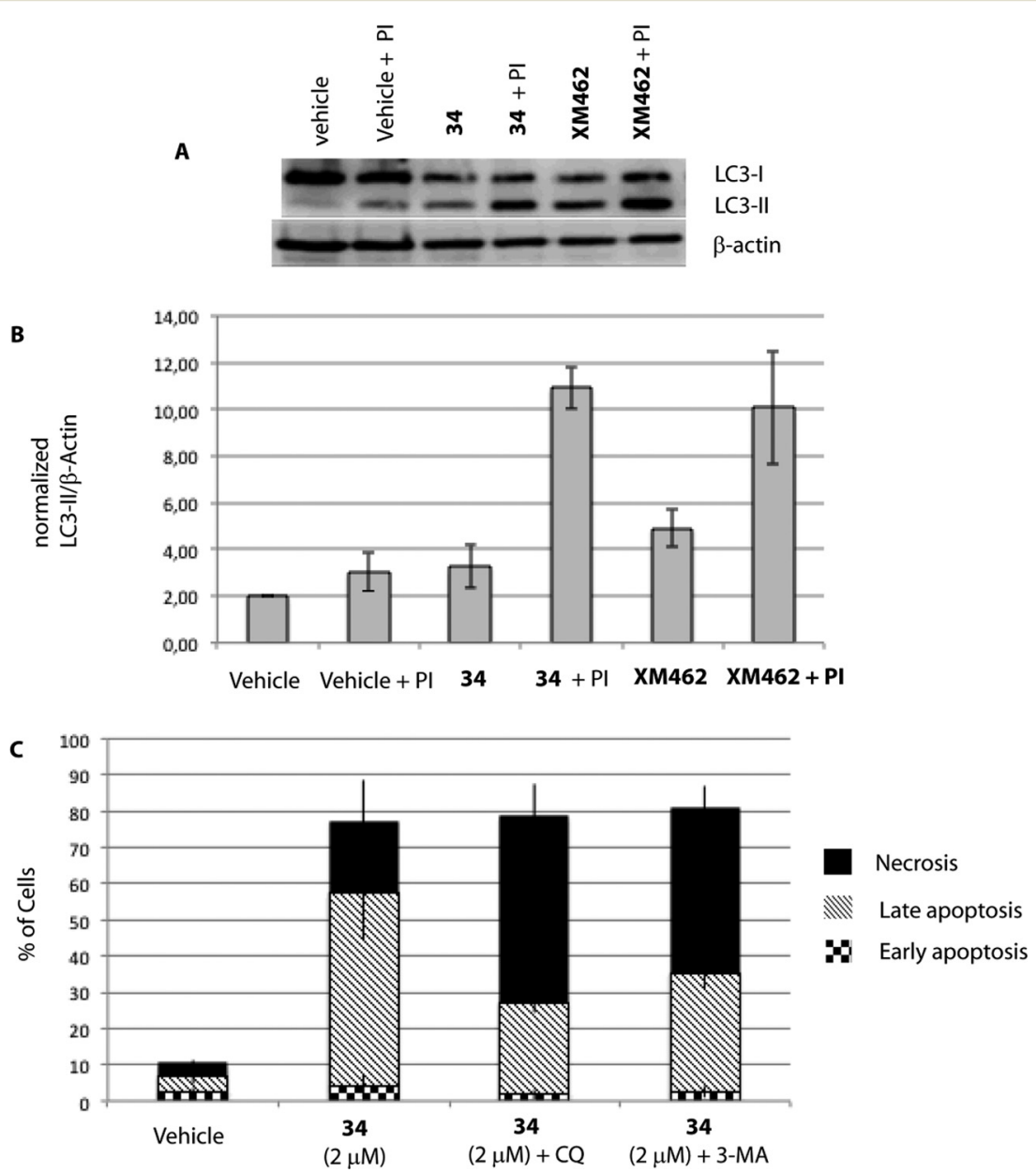

Fig. 5 HGC-27 cells were exposed to 34 for 24 h. A) Levels of LC3-II were assessed by Western blotting of cell lysates as described in the Experimental procedures. XM462 (10 $\mu$ M), a known autophagy inducer in HGC-27 cells, was used as a positive control. ${ }^{47}$ The images shown are representative of three independent experiments with similar results. B) Quantified LC3-II levels with respect to $\beta$-actin. C) Effect of autophagy inhibition on apoptosis/necrosis of treated HGC-27 cells. Cells were treated with DMSO (vehicle group), 34 alone, chloroquine (CQ, $50 \mu M$ in EtOH) or 3-methyladenine (3-MA, $2 \mathrm{mM}$ in DMSO). The cells were pre-treated for $2 \mathrm{~h}$ with CQ or $3 \mathrm{~h}$ with 3-MA before adding 34 . After $24 \mathrm{~h}$ of treatment, the cells were double-stained with Annexin V and PI and analysed. The percentage of apoptotic and necrotic cells upon incubation with 34 were quantified by flow cytometry as described in the Experimental section (live cells (bottom left quadrant), early apoptotic cells (bottom right quadrant), late apoptotic cells (upper right quadrant) and necrotic cells (upper left quadrant)). The graph shows the quantitative analysis of necrosis and early and late apoptosis in cells treated with 34 . The data were obtained from three independent experiments. 
necrotic and live cells upon autophagy inhibition was analysed. As shown in Fig. 5, co-treatment of 34 with autophagy inhibitors such as CQ or 3-MA did not increase the number of live cells, but on the contrary significantly increased the number of necrotic cells. Taken all together, all data described above suggest that autophagy is triggered by 34 exposure to $\mathrm{HGC}-27$ cells as a protective response to alleviate its cytotoxicity. Moreover, the fact that cathepsin inhibition, which causes lysosomal dysfunction, results also in increased cell death may underscore the pro-survival function of autophagy, which requires a correct lysosomal function to take place (Fig. 4). ${ }^{39}$

\subsection{Mitochondria and ROS}

MTT assays measure the activity of succinate dehydrogenase, a mitochondrial enzyme, hence reflecting the activity status of this organelle and suggesting that the differences observed in both cell viability methods employed above (MTT vs. ATPbased assay) may occur due to mitochondrial damage, which would be in agreement with the increased viability upon treatment with the caspase-9 inhibitor, a marker of the intrinsic mitochondrial pathway.

If the intrinsic mitochondrial pathway is activated, there are alterations in the inner mitochondrial membrane, resulting in changes in transmembrane potential, loss of membrane permeability and activation of caspase. Therefore, we next investigated the mitochondrial membrane potential in HGC-27 cells treated with squaramide 34 . JC-1 accumulates as aggregates in the mitochondria (orange color) and the color changes from orange to green fluorescence in apoptotic cells with depolarization of mitochondrial membrane potential, where JC-1 exists in the monomeric form. ${ }^{40}$ Therefore, JC-1 has been widely used to detect mitochondrial depolarization during apoptosis. The results showed that 34 efficiently caused mitochondrial membrane depolarization. When $\Delta \Psi_{\mathrm{m}}$ levels were assessed quantitatively by the ratio of orange/green fluorescence intensity, there was a significant reduction of $\Delta \Psi_{\mathrm{m}}$ in HGC-27 cells compared to control cells after a $2 \mu \mathrm{M}$ and $8 \mu \mathrm{M}$ treatment for $24 \mathrm{~h}$ (Fig. 6), which indicates that compound 34 induces $\Delta \Psi_{\mathrm{m}}$ changes in HGC-27 cells during apoptosis. These results confirmed the implication of the intrinsic pathway in the 34-mediated cell death.

Reactive oxygen species (ROS) are known triggers of the intrinsic apoptotic cascade. ${ }^{41}$ Therefore, oxidative damage caused by the generation of ROS may be one of the underlying mechanisms of 34-mediated cell death. To elucidate whether oxidative stress mediated by ROS generation plays a critical role in the onset of cell death caused by 34 , we determined the changes in the intracellular redox potential upon treatment with $\mathbf{3 4}$ by employing the fluorescent probe $2^{\prime}, 7^{\prime}$-dichlorofluorescein diacetate (DCFH-DA), which is converted to highly fluorescent dichlorofluorescein (DCF) in the presence of intracellular ROS. However, although a remarkable increase in ROS formation was detected when $\mathrm{H}_{2} \mathrm{O}_{2}$ was employed as a positive control, no signs of ROS production

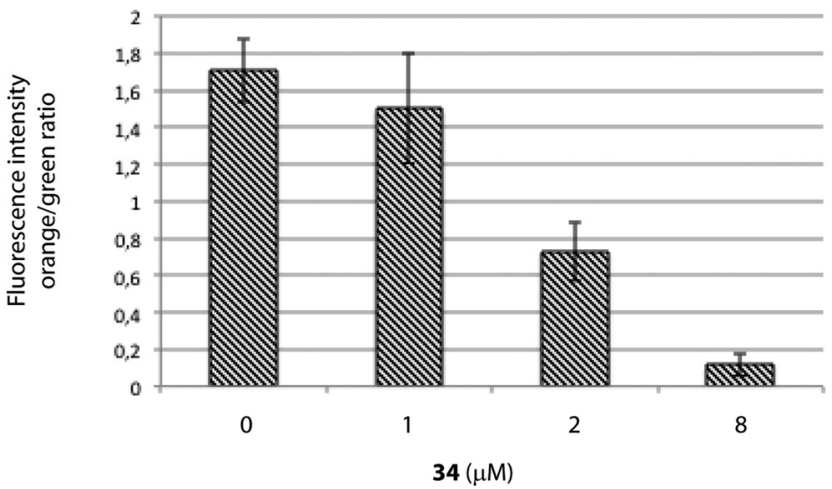

Fig. 6 Mitochondrial membrane potential in 34-treated HGC-27 cells evaluated by JC-1 staining and flow cytometry analysis. Quantification of the orange/green ratio. Data are the average \pm SD of three experiments.

could be detected in HGC-27 treated cells, thus discarding the implication of oxidative damage in the molecular mechanism responsible for 34-mediated cell death (Fig. S2 $\ddagger$ ).

\section{Summary and conclusions}

In this study, it has been shown that substituted squaramide 34 effectively inhibited the proliferation of HGC-27 cells in a concentration-dependent manner. These inhibitory effects were associated with the cell cycle arrest and induction of apoptosis dependent of caspases that implicates the activation of the intrinsic pathway and the subsequent mitochondrial membrane depolarization. The implication of ROS as stimuli for the activation of the intrinsic pathway has been discarded, suggesting that other stimuli or pro-apoptotic proteins may be involved in the activation of the intrinsic pathway. Apart from the observed caspase-dependent apoptosis, no signs of cathepsin-mediated cell death or necroptosis have been detected. Moreover, the cell death caused by 34 is accompanied by autophagy induction having a protective effect. These overall results indicate that the decrease in cell viability caused by squaramide 34 is most likely mediated by $G_{0} / G_{1}$ cell cycle arrest and caspase-mediated apoptosis. Since the identification of compounds inducing a specific cell death subroutine is preferred to avoid side-effects and nonspecific cytotoxic effects, squaramide 34 can be considered a promising agent for the treatment of gastric carcinoma. Moreover, although 34 presents an specific effect on HGC-27 cells vs. HeLa, U87 and T98 cells, similar anti-tumor effects on other epithelial tumor types, particularly those of the GI tract, cannot be discarded and will be characterized in future studies.

\section{Experimental section}

\section{Materials}

Minimum essential medium eagle, fetal bovine serum, nonessential amino acids, 3-[4,5-dimethylthiazol-2-yl]-2,5diphenyltetrazolium bromide (MTT), BSA, NADH, Tween 20, trypsin-EDTA, chloroquine diphosphate, 3-methyladenine, necrostatin-1, pepstatin A, C8-ceramide, doxorubicin, 2',7'- 
dichlorofluorescein diacetate and protease inhibitors were obtained from Sigma. Laemmli buffer and acrylamide were procured from BioRad, SDS from Fluka, and the microBCA protein assay kit from Thermo Scientific. The protease inhibitor cocktail contained $2 \mu \mathrm{g} \mathrm{ml}^{-1}$ aprotinin, $5 \mu \mathrm{g} \mathrm{ml}{ }^{-1}$ leupeptin, and $1 \mathrm{mM}$ phenylmethylsulphonyl fluoride. Z-VAD-FMK and E-64-D were acquired from Enzo Life Science. Z-IEDT-FMK and Z-LEHD-FMK were purchased from Alfa Aesar and cathepsin inhibitor III from CalBioChem. Annexin V-FITC early apoptosis detection kit was obtained from Cell Signaling. Antibodies: microtubule-associated protein 1-light chain 3 (LC3) II (rabbit) was obtained from Abcam, and $\beta$-actin (mouse) was purchased from Sigma. HRP secondary antibodies were acquired from GE Healthcare.

\section{General experimental methods}

Purification of reaction products was carried out either by filtration or by flash chromatography using silica gel (0.063$0.200 \mathrm{~mm}$ ). Analytical thin layer chromatography was performed on $0.25 \mathrm{~mm}$ silica gel $60-\mathrm{F}$ plates. The ESI ionization method and a mass analyzer type MicroTof-Q were used for ESI measurements. ${ }^{1} \mathrm{H}-\mathrm{NMR}$ spectra were recorded at 300 and $400 \mathrm{MHz} ;{ }^{13} \mathrm{C}-\mathrm{NMR}-\mathrm{APT}$ spectra were recorded at 75 and $100 \mathrm{MHz} ; \mathrm{CDCl}_{3}$ and DMSO- $d_{6}$ were used as solvents. Chemical shifts were reported in the $\delta$ scale relative to residual $\mathrm{CHCl}_{3}(7.26 \mathrm{ppm})$ and DMSO (2.50 ppm) for ${ }^{1} \mathrm{H}-\mathrm{NMR}$ and to the central line of $\mathrm{CDCl}_{3}(77 \mathrm{ppm})$ and DMSO- $d_{6}(39.43 \mathrm{ppm})$ for ${ }^{13} \mathrm{C}$-NMR-APT. All commercially available solvents and reagents were used as received.

\section{Representative procedure for the synthesis of squaramates} and squaramides

To a mixture of 3,4-dimethoxy-3-cyclobutene-1,2-dione $(0.2 \mathrm{mmol})$ in $\mathrm{MeOH}(0.75-1.5 \mathrm{ml})$, appropriate amine $(0.2$ mmol) was added at room temperature. After the appropriate reaction time, the corresponding squaramate was purified either by filtration, washing with $\mathrm{MeOH}$ at $-25{ }^{\circ} \mathrm{C}$, or column chromatography (see the ESI $\ddagger$ ). Squaramate $\mathbf{1}$ is commercially available. The ${ }^{1} \mathrm{H}$ and ${ }^{13} \mathrm{C}$-NMR spectral data for squaramates $2,{ }^{42} 3,,^{10} 4,{ }^{42} 9,{ }^{42}$ and $10,{ }^{42}$ are consistent with values previously reported in the literature. For spectral and analytical data for all new squaramates (5-8 and 11-14), see the ESI.

Squaramides 15-39 were synthesized following our own reported procedure. ${ }^{20,22}$ The ${ }^{1} \mathrm{H}$ and ${ }^{13} \mathrm{C}-\mathrm{NMR}$ spectral data for squaramides $15-18,{ }^{43} 19,,^{44} 20,{ }^{1} 21,{ }^{20} 22,,^{20} 23,{ }^{20} 24,,^{20}$ $25,^{20} 26,{ }^{1} 27,,^{45} 28,,^{20} 29,{ }^{46} 30,{ }^{43} 31,{ }^{20} 32,{ }^{20} 33,{ }^{20} 34,{ }^{20} 35,{ }^{20}$ $36,{ }^{20} 37,{ }^{45} 38,{ }^{20}$ and $39,,^{20}$ are consistent with values previously reported in the literature.

\section{Cell culture}

The human gastric cancer cell line HGC-27 was cultured at $37{ }^{\circ} \mathrm{C}$ in $5 \% \mathrm{CO}_{2}$ in minimum essential medium supplemented with $10 \%$ fetal bovine serum and $1 \%$ nonessential amino acids. Cells were routinely grown at $80 \%$ maximum confluence. Glioblastoma cells T98G and U87 as well as
HEK293 and HeLa cells were maintained at $37{ }^{\circ} \mathrm{C}$ in $5 \% \mathrm{CO}_{2}$ in Dulbecco's modified Eagle's medium supplemented with $10 \%$ fetal bovine serum and $100 \mathrm{ng} \mathrm{ml}^{-1}$ each of penicillin and streptomycin.

\section{Cell viability assay}

To determine cell viability, the colorimetric MTT metabolic activity assay was employed. Cells were seeded at a density of $0.1 \times 10^{6}$ cells ml ${ }^{-1}, 0.1 \mathrm{ml}$ per well (96-well plates) and cultured at $37{ }^{\circ} \mathrm{C}$ and $5 \% \mathrm{CO}_{2}$. Twenty-four hours after seeding, cells were exposed to varying concentrations of the investigated compounds and viability was determined $24 \mathrm{~h}$ or $48 \mathrm{~h}$ later. The control culture was prepared by addition of culture medium (cell viability control) or DMSO (vehicle control) in the absence of treatment. The stock solution of doxorubicin was prepared in water. After $24 \mathrm{~h}$ or $48 \mathrm{~h}$ of treatment, MTT solution (10 $\mu \mathrm{l}$ at $5 \mathrm{mg} \mathrm{ml}^{-1}$ in PBS) was added to each well and the cells were incubated for another $3 \mathrm{~h}$. The solution was removed from the precipitate and the resulting formazan crystals were dissolved in DMSO $(100 \mu \mathrm{l})$ and the absorbance intensity was measured using a microplate reader (Molecular Devices, SpectramaxM5) at $570 \mathrm{~nm}$. All experiments were performed in triplicate, and the relative cell viability (\%) is expressed as the percentage of cell viability relative to the cells treated with DMSO (0.1\%, vehicle group).

\section{SRB assay}

Cells were seeded at a density of $0.1 \times 10^{6}$ cells per $\mathrm{ml}, 0.1 \mathrm{ml}$ per well (96-well plates) and cultured at $37{ }^{\circ} \mathrm{C}$ and $5 \% \mathrm{CO}_{2}$. Twenty-four hours after seeding, cells were exposed to varying concentrations of 34 and viability was determined after $24 \mathrm{~h}$. The control culture was prepared by addition of DMSO (vehicle control) in the absence of treatment. After $24 \mathrm{~h}, 50 \mu \mathrm{l}$ of TCA $(50 \% \mathrm{w} / \mathrm{v})$ and $200 \mu \mathrm{l}$ of PBS were added to each well and the cells were incubated for $1 \mathrm{~h}$ at $4{ }^{\circ} \mathrm{C}$. The solution was then removed and the plate was washed with Milli-Q water four times. After that, $100 \mu$ per well of SRB solution (0.4\% sulforhodamine $\mathrm{B} w / \mathrm{v}$ in $\mathbf{0 . 1 \%}$ acetic acid) was added and the samples were incubated for another $30 \mathrm{~min}$ at room temperature. The plate was then washed with $1 \%$ acetic acid five times and $200 \mu \mathrm{l}$ of a $10 \mathrm{mM}$ Tris solution ( $\mathrm{pH}$ 10.5) were added to each well. After $30 \mathrm{~min}$ of incubation at room temperature, the absorbance intensity was measured using a microplate reader (Molecular Devices, SpectramaxM5) at $564 \mathrm{~nm}$. All experiments were performed in triplicate, and the relative cell viability (\%) is expressed as the percentage of cell viability relative to the cells treated with DMSO $(0.1 \%$, vehicle group).

\section{Cell cycle analysis}

Cells were seeded at 150000 cells per $\mathrm{ml}$ in 6-well plates ( $1 \mathrm{ml}$ per well). Cells were allowed to adhere for $24 \mathrm{~h}$, and then they were treated with the vehicle $(0.1 \%$ ethanol) or 34 . After exposure for $24 \mathrm{~h}$, cell media were discarded and cells were washed with $400 \mu \mathrm{l}$ of PBS-EDTA (1\% BSA) and 
harvested with $400 \mu \mathrm{l}$ of trypsin-EDTA (1\% BSA) $\left(37^{\circ} \mathrm{C}\right.$ per $2 \mathrm{~min})$. Cells were pulled down by centrifugation at $1300 \mathrm{rpm}$ per $3 \mathrm{~min}$; the cell pellet was washed once with $400 \mu \mathrm{l}$ of PBS-EDTA (1\% BSA) and again centrifuged at the same speed/time. Cells were fixed by $-20{ }^{\circ} \mathrm{C}$ overnight incubation with $70 \%$ ethanol $(9.5 \mathrm{ml})$ in $1 \times$ PBS solution $(0.5 \mathrm{ml})$. Fixed cells were pulled down, washed once with PBS-EDTA (1\% BSA) and stained at $37^{\circ} \mathrm{C}$ for $2 \mathrm{~h}$ with propidium iodide solution (0.1 $\mathrm{mg} \mathrm{ml}^{-1}$ in PBS) and RNase, DNase-free (10 $\mu \mathrm{g}$ $\mathrm{ml}^{-1}$ ). Stained cells were analyzed by using a Guava EasyCyte $^{\mathrm{TM}}$ flow cytometer (Merck Millipore, Billerica, MA). Data analysis was performed using the program Multicycle AV (Phoenix Flow Systems, San Diego, CA).

\section{Apoptosis assay}

HGC-27 cells were plated in 6-well plates (100000 cells per $\mathrm{ml}$ per well) and were treated with compound $34 ; 0.1 \%$ DMSO was used as a vehicle control. After induction for $24 \mathrm{~h}$, both treated and untreated cells were collected (trypsin and PBS with 5\% BSA) and the cells were washed with PBS containing 5\% BSA. The percentages of apoptotic cells were estimated by staining with Annexin-V-FITC and PI (Annexin-VFITC apoptosis detection kit, Cell Signaling). Almost 10000 events were collected for each sample and analyzed by flow cytometry. In brief, cells were incubated with $96 \mu \mathrm{l}$ of binding buffer, $1 \mu$ l of Annexin V-FITC and $12.5 \mu \mathrm{l}$ of PI solution at room temperature for $10 \mathrm{~min}$ in the dark. After a final addition of $150 \mu$ l of PBS, HGC-27 cells were immediately analyzed on a Guava EasyCyte ${ }^{\mathrm{TM}}$ single sample flow cytometer. Samples were excited by a light wavelength of $488 \mathrm{~nm}$ with barrier filters of $525 \mathrm{~nm}$ and $575 \mathrm{~nm}$ for FITC fluorescence and PI detection, respectively. Data were analyzed by InCyte Software and plotted for Annexin V-FITC and PI in a two-way dot plot. Live, early apoptotic, late apoptotic and necrotic cells are designed as Annexin-/PI-, Annexin+/PI-, and Annexin+/PI+, respectively. Results are shown as the percentage of cells.

\section{Western blotting}

For protein analysis, $1 \times 10^{5}$ cells were plated in 6-well plates and were allowed to adhere for $24 \mathrm{~h}$. In the samples containing protease inhibitors, cells were treated with protease inhibitors, $1 \mu \mathrm{l}$ of pepstatin A at a concentration of $1 \mathrm{mg}$ $\mathrm{ml}^{-1}$ in 9:1 of methanol and acetic acid (1\%), and $1 \mu \mathrm{l}$ of E-64-D at a concentration of $10 \mathrm{mg} \mathrm{ml}^{-1}$ in ethanol. After $2 \mathrm{~h}$ of incubation, HGC-27 cells were treated with $34(2 \mu \mathrm{M})$ or DMSO $(0.1 \%)$ for $24 \mathrm{~h}$, collected with trypsin, and then the pellets were washed twice with cold PBS. Cell lysis was performed with $30 \mu \mathrm{l}$ of lysis buffer (50 mM Tris-Cl (pH 7.5), $150 \mathrm{mM} \mathrm{NaCl}, 0.5 \%$ Triton $\mathrm{X}-100,2 \mu \mathrm{g} \mathrm{ml} \mathrm{m}^{-1}$ aprotinin, $5 \mu \mathrm{g}$ $\mathrm{ml}^{-1}$ leupeptin and $1 \mathrm{mM}$ PMSF) by five cycles of bath sonication $(20 \mathrm{~s}) /$ rest on ice $(20 \mathrm{~s})$. Then samples were kept on ice for $30 \mathrm{~min}$ and centrifuged for $3 \mathrm{~min}$ at $10000 \mathrm{rpm}$. Supernatants were collected and protein determination was performed using the Micro BCA $^{\text {TM }}$ protein assay kit. Superna- tants were combined with Laemmli sample buffer and boiled for $5 \mathrm{~min}$. Equal amounts of proteins $(20 \mu \mathrm{g})$ were loaded onto a $15 \%$ polyacrylamide gel, separated by electrophoresis at $140 \mathrm{~V}$ per $60 \mathrm{~min}$, and transferred onto a polyvinylidene fluoride (PVDF) membrane (100 V/1 h). PVDF membranes were then cut to separate LC3B and $\beta$-actin bands. Unspecific binding sites were then blocked with $5 \%$ milk in TBS with $0.1 \%$ Tween 20 (TBST) in the case of the LC3B membrane and with $3 \%$ BSA in TBST in the case of the anti- $\beta$-actin antibody. The anti-LC3B antibody was diluted 1:1000 in 5\% milk in TBST, and the anti- $\beta$-actin antibody was diluted $1: 2000$ in $3 \%$ BSA in TBST. Membranes were incubated overnight at $4{ }^{\circ} \mathrm{C}$ under gentle agitation. After washing with TBST, membranes were probed with the corresponding secondary antibody for $1 \mathrm{~h}$ at $25{ }^{\circ} \mathrm{C}$ (LC3B: $1: 1000$ dilution in 3\% BSA in TBST; actin: 1:10 000 dilution in 5\% milk in TBST). Antibody excess was eliminated by washing with TBST and protein detection was carried out using ECL and membrane scanning with a LI-COR C-DiGit ${ }^{\circledR}$ blot scanner. Band intensities were quantified by LI-COR Image Studio Lite Software. All experiments were performed in triplicate and band intensities were expressed as the relation of the samples with the control.

\section{Mitochondrial membrane potential}

HGC-27 cells were seeded at a density of 100000 cells per ml ( $1 \mathrm{ml}$ per well) in 6-well plates, cultured at $37{ }^{\circ} \mathrm{C}$ and $5 \%$ $\mathrm{CO}_{2}$, and allowed to adhere for $24 \mathrm{~h}$. Cells were treated with 34 at various concentrations $(1 \mu \mathrm{M}, 2 \mu \mathrm{M}, 8 \mu \mathrm{M}$ in DMSO) or DMSO (0.2\%) as negative control (vehicle group). After $24 \mathrm{~h}$ of incubation, cells were collected (trypsin with 5\% BSA) and washed with PBS containing 5\% BSA. The cell pellet was then resuspended in $200 \mu \mathrm{l}$ of medium and seeded in a 96-well plate ( 1 sample per well). $4 \mu \mathrm{l}$ of a previously prepared $50 \times$ solution of JC-1 and 7-AAD were added to each well and cells were incubated for $30 \mathrm{~min}$ at $37{ }^{\circ} \mathrm{C}$ and $5 \% \mathrm{CO}_{2}$. Finally, cells were collected in Eppendorf flasks and analysed on a Guava EasyCyte $^{\text {тм }}$ Single Sample Flow Cytometer. Data were analyzed by InCyte Software and plotted for orange (JC-1 aggregates) and green fluorescence (JC-1 monomers).

\section{ROS detection}

The oxidative metabolism was examined in triplicate samples by using 2 ',7'-dichlorofluorescein diacetate, a non-fluorescent membrane-permeable compound which can be oxidised to $2^{\prime}, 7^{\prime}$-dichlorofluorescein in case the cell has high levels of reactive oxygen species.

HGC-27 cells were seeded at a density of $0.1 \times 10^{6}$ cells per $\mathrm{ml}, 0.1 \mathrm{ml}$ per well (96-well plates), cultured at $37^{\circ} \mathrm{C}$ and $5 \%$ and allowed to adhere for 24 h. 2',7'-Dichlorofluorescein diacetate $(25 \mu \mathrm{M})$ in DMSO was then added and incubated for $1 \mathrm{~h}$. Compound 34 was then added at various concentrations (24 to $1.40 \mu \mathrm{M}$ ). DMSO and $\mathrm{H}_{2} \mathrm{O}_{2}$ were added too as a negative and positive control, respectively. After $5 \mathrm{~h}$ of incubation, fluorescence was measured by a microplate reader 
(Spectramax) at an excitation wavelength of $485 \mathrm{~nm}$ and an emission wavelength of $538 \mathrm{~nm}$.

\section{Acknowledgements}

Funding from the Marie Curie Career Integration Grants (Grant PCIG12-GA-2012-333835), the Max Planck Society (Partner Groups), the Ministerio de Economia y Competitividad (Grant CTQ2013-44334-P), the University of Zaragoza (JIUZ-2014-CIE07), the High Council of Scientific Investigation (CSIC) (PIE201580I010) and Government of Aragon DGA (Research Group E-104) is gratefully acknowledged. J. V. A.-R. thanks the DGA for his predoctoral contract. G. T. thanks all the members of the RUBAM group for their helpful and generous support.

\section{Notes and references}

1 J. P. Malerich, K. Hagihara and V. H. Rawal, J. Am. Chem. Soc., 2008, 130, 14416-14417.

2 P. Chauhan, S. Mahajan, U. Kaya, D. Hack and D. Enders, Adv. Synth. Catal., 2015, 357, 253-281.

3 J. V. Alegre-Requena, Synlett, 2014, 25, 298-300.

4 J. Aleman, A. Parra, H. Jiang and K. A. Jørgensen, Chem. Eur. J., 2011, 17, 6890-6899.

5 D. Quiñonero, C. Garau, A. Frontera, P. Ballester, A. Costa and P. M. Deya, Chem. - Eur. J., 2002, 8, 433-438.

6 C. Rotger, B. Soberats, D. Quiñonero, A. Frontera, P. Ballester, J. Benet-Buchholz, P. M. Deyà and A. Costa, Eur. J. Org. Chem., 2008, 1864-1868.

7 R. I. Storer, C. Aciro and L. H. Jones, Chem. Soc. Rev., 2011, 40, 2330-2346.

8 E. T. Buurman, M. A. Foulk, N. Gao, V. A. Laganas, D. C. McKinney, D. T. Moustakas, J. A. Rose, A. B. Shapiro and P. R. Fleming, J. Bacteriol., 2012, 194, 5504-5512.

9 T. S. Elliott, A. Slowey, Y. Ye and S. J. Conway, MedChemComm, 2012, 3, 735-751.

10 P. M. Gloria, J. Gut, L. M. Gonçalves, P. J. Rosenthal, R. Moreira and M. M. Santos, Bioorg. Med. Chem., 2011, 19, 7635-7642.

11 S. P. Kumar, P. M. Gloria, L. M. Gonçalves, J. Gut, P. J. Rosenthal, R. Moreira and M. M. Santos, MedChemComm, 2012, 3, 489.

12 S. K. Narasimhan, P. Sejwal, S. Zhu and Y. Y. Luk, Bioorg. Med. Chem., 2013, 21, 2210-2216.

13 F. Olmo, C. Rotger, I. Ramirez-Macias, L. Martinez, C. Marin, L. Carreras, K. Urbanova, M. Vega, G. ChavesLemaur, A. Sampedro, M. J. Rosales, M. Sanchez-Moreno and A. Costa, J. Med. Chem., 2014, 57, 987-999.

14 C. Schieber, A. Bestetti, J. P. Lim, A. D. Ryan, T. L. Nguyen, R. Eldridge, A. R. White, P. A. Gleeson, P. S. Donnelly, S. J. Williams and P. Mulvaney, Angew. Chem., Int. Ed., 2012, 51, 10523-10527.

15 Q. Zhang, Z. Xia, M. J. Mitten, L. M. Lasko, V. Klinghofer, J. Bouska, E. F. Johnson, T. D. Penning, Y. Luo, V. L. Giranda, A. R. Shoemaker, K. D. Stewart, S. W. Djuric and A. Vasudevan, Bioorg. Med. Chem. Lett., 2012, 22, 7615-7622.
16 X. Zhang, Z. Zuo, J. Tang, K. Wang, C. Wang, W. Chen, C. Li, W. Xu, X. Xiong, K. Yuntai, J. Huang, X. Lan and H. B. Zhou, Bioorg. Med. Chem. Lett., 2013, 23, 3793-3797.

17 J. W. Janetka and S. Ashwell, Expert Opin. Ther. Pat., 2009, 19, 165-197.

18 P. Villalonga, S. Fernandez de Mattos, G. Ramis, A. ObradorHevia, A. Sampedro, C. Rotger and A. Costa, ChemMedChem, 2012, 7, 1472-1480.

19 M. P. Dwyer, Y. Yu, J. Chao, C. Aki, J. Chao, P. Biju, V. Girijavallabhan, D. Rindgen, R. Bond, R. Mayer-Ezel, J. Jakway, R. W. Hipkin, J. Fossetta, W. Gonsiorek, H. Bian, X. Fan, C. Terminelli, J. Fine, D. Lundell, J. R. Merritt, L. L. Rokosz, B. Kaiser, G. Li, W. Wang, T. Stauffer, L. Ozgur, J. Baldwin and A. G. Taveras, J. Med. Chem., 2006, 49, 7603-7606.

20 J. V. Alegre-Requena, E. Marqués-López and R. P. Herrera, RSC Adv. , 2015, 5, 33450-33462.

21 J. V. Alegre-Requena, E. Marqués-López, P. J. Sanz Miguel and R. P. Herrera, Org. Biomol. Chem., 2014, 12, 1258-1264.

22 E. Marqués-López, J. V. Alegre-Requena and R. P. Herrera, Eu. Pat. EP14382260., 2014.

23 A. Cervantes, D. Roda, N. Tarazona, S. Rosello and J. A. Perez-Fidalgo, Cancer Treat. Rev., 2013, 39, 60-67.

24 A. Jemal, F. Bray, M. M. Center, J. Ferlay, E. Ward and D. Forman, CA Cancer J. Clin., 2011, 61, 69-90.

25 O. Kepp, L. Galluzzi, M. Lipinski, J. Yuan and G. Kroemer, Nat. Rev. Drug Discovery, 2011, 10, 221-237.

26 G. Liu, J. K. Lynch, J. Freeman, B. Liu, Z. Xin, H. Zhao, M. D. Serby, P. R. Kym, T. S. Suhar, H. T. Smith, N. Cao, R. Yang, R. S. Janis, J. A. Krauser, S. P. Cepa, D. W. Beno, H. L. Sham, C. A. Collins, T. K. Surowy and H. S. Camp, J. Med. Chem., 2007, 50, 3086-3100.

27 H. G. Yu, Y. W. Ai, L. L. Yu, X. D. Zhou, J. Liu, J. H. Li, X. M. $\mathrm{Xu}$, S. Liu, J. Chen, F. Liu, Y. L. Qi, Q. Deng, J. Cao, S. Q. Liu, H. S. Luo and J. P. Yu, Int. J. Cancer, 2008, 122, 433-443.

28 V. Vichai and K. Kirtikara, Nat. Protoc., 2006, 1, 1112-1116.

29 S. Elmore, Toxicol. Pathol., 2007, 35, 495-516.

30 A. B. Berger, K. B. Sexton and M. Bogyo, Cell Res., 2006, 16, 961-963.

31 S. Aits and M. Jaattela, J. Cell Sci., 2013, 126, 1905-1912.

32 T. Kirkegaard and M. Jaattela, Biochim. Biophys. Acta, Gen. Subj., 2009, 1793, 746-754.

33 H. Sawai and N. Domae, Biochem. Biophys. Res. Commun., 2011, 411, 569-573.

34 G. Triola, Tetrahedron, 2015, 71, 387-406.

35 R. Castino, I. Fiorentino, M. Cagnin, A. Giovia and C. Isidoro, Toxicol. Sci., 2011, 123, 523-541.

36 M. Elgendy, C. Sheridan, G. Brumatti and S. J. Martin, Mol. Cell, 2011, 42, 23-35.

37 M. Katayama, T. Kawaguchi, M. S. Berger and R. O. Pieper, Cell Death Differ., 2007, 14, 548-558.

38 G. Kroemer and B. Levine, Nat. Rev. Mol. Cell Biol., 2008, 9, 1004-1010.

39 M. Jung, J. Lee, H. Y. Seo, J. S. Lim and E. K. Kim, PLoS One, 2015, 10, e0116972.

40 J. D. Ly, D. R. Grubb and A. Lawen, Apoptosis, 2003, 8, 115-128. 
41 Y. Tsujimoto and S. Shimizu, Apoptosis, 2007, 12, 835-840.

42 M. C. Brezak Pannetier and A. Bourgouin, Pat. WO2009/ 034258 A1, 2009.

43 W. Yang and D. M. Du, Adv. Synth. Catal., 2011, 353, 1241-1246.

44 H. Jiang, M. W. Paixao, D. Monge and K. A. Jørgensen, J. Am. Chem. Soc., 2010, 132, 2775-2783.
45 H. Konishi, T. Y. Lam, J. P. Malerich and V. H. Rawal, Org. Lett., 2010, 12, 2028-2031.

46 Y. Zhu, J. P. Malerich and V. H. Rawal, Angew. Chem., Int. Ed., 2010, 49, 153-156.

47 P. Signorelli, J. M. Munoz-Olaya, V. Gagliostro, J. Casas, R. Ghidoni and G. Fabrias, Cancer Lett., 2009, 282, 238-243. 